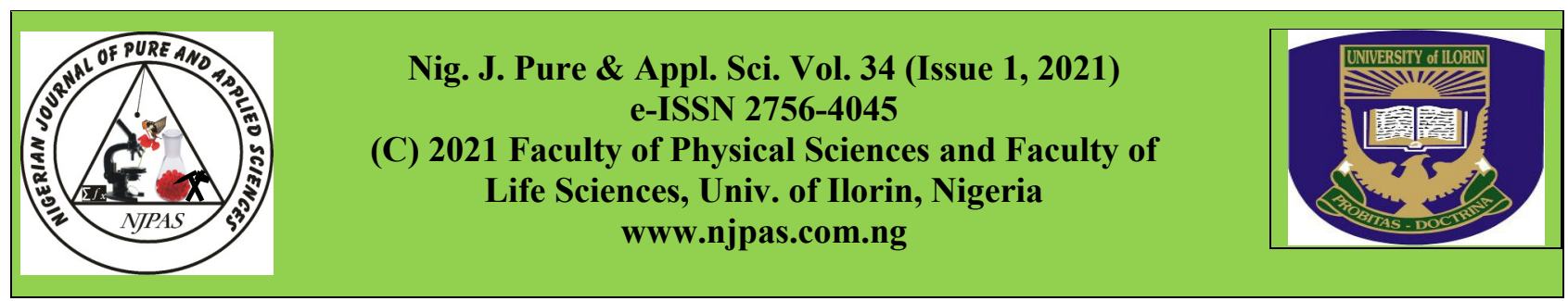

http://dx.doi.org/10.48198/NJPAS/20.B04

\title{
IMPACT OF IRRIGATIONAL RUNOFF ON FISH BIODIVERSITY IN RIVER NGADDA, MAIDUGURI - BORNO STATE
}

\author{
*Mathias Nzitiri Bwala \\ Page | 3981 National Environmental Standards and Regulations Enforcement Agency, (NESREA), Borno State Field Office, \\ Maiduguri, Nigeria
}

\begin{abstract}
Irrigation is a dry season agricultural activity that was known to man for centuries. Agricultural runoff has been identified as the major nonpoint sources of pollution into surface waterbodies which changes the physico chemical parameters thereby impacting on the biodiversity of such ecosystem. River Ngadda receives pollutants from the irrigational sites along the river bank. The study was aimed at assessing the impact of irrigation on fish biodiversity in river Ngadda, Maiduguri, Borno State, Nigeria. The objectives of the study were to determine the physico - chemical parameters and examine the fish biodiversity of the river. The river was divided into 4 sampling Stations. Water samples was collected biweekly for the period of 6 months from 4 sampling stations. The physico - chemical qualities (total nitrogen (TN), ammonium $\left(\mathrm{NH}^{+}\right)$, total phosphorus (TP), total organic carbon (TOC), total dissolved solids (TDS), turbidity (Tur) and total suspended solids (TSS) were determined using standard methods. Capture and recapture method was employed to determine the relative abundance of fish species using Lincoln index. The mean Total Nitrogen (TN) ranges from $5.02 \mathrm{mg} / \mathrm{L}-8.31 \mathrm{mg} / \mathrm{L}$, mean ammonium $\left(\mathrm{NH}^{+}\right.$) ranges from $0.93 \mathrm{mg} / \mathrm{L}-2.01$, mean Total phosphorous $(\mathrm{TP})$ ranges from $0.07 \mathrm{mg} / \mathrm{L}-$ $1.81 \mathrm{mg} / \mathrm{L}$. mean Total Organic Carbon (TOC) ranges $5.87 \mathrm{mg} / \mathrm{L}-7.45 \mathrm{mg} / \mathrm{L}$, mean Turbidity (Tur) ranges from $27 \mathrm{mg} / \mathrm{L}-31 \mathrm{mg} / \mathrm{L}$, mean Total Dissolved Solids (TDS) ranges 198NTU - 298NTU, mean Total Suspended Solids ranges from $34 \mathrm{mg} / \mathrm{L}-47 \mathrm{mg} / \mathrm{L}$ and mean surface water Temperature ranges from $26^{\circ} \mathrm{C}-28^{\circ} \mathrm{C}$. A total of 4 families and 10 species of fishes were identified in the sampling stations.
\end{abstract}

Keywords: Non-Point Pollution, Irrigation, River Ngadda

\section{Introduction}

Irrigation is a dry season agricultural farming practice that was known to man for centuries. Irrigation as an agricultural practice involves the controlled supply of water needed by crops for their growth and survival. Generally, agricultural runoff as being identified as the major nonpoint sources of pollution into surface waterbodies which changes the physico - chemical parameters of such aquatic environment thereby affecting the biodiversity inhabiting that particular aquatic environment (Verma and Agarwal, 2008; Shunsuke et al, 2009; Harris, 2012). Irrigational runoff drill into streams, rivers and lakes along with diluted chemicals, such as pesticides and fertilizers deteriorating the water quality, impacting on the aquatic ecosystem via influencing 
the abundance and distribution of the aquatic bio resource, (Verma and Agarwal 2008; Govind, 2012; Bwala, 2019).

Land use and physico - chemical characteristics of soil as been identified as key factors in regulating

Page | 3982 the quantity and quality of runoff in a site (Ron, 2012; Syed, 2011; Luke and Fleming, 2010; Verma and Agarwal, 2008).

The insurgency in North eastern, Nigeria and particularly Borno State with an estimated one third of its population displaced. The State capital, Maiduguri became the major city of refuge to the displaced individuals (https://www.unicef.org/ nigeria). The town has witnessed a rapid change in population, land use and economic activities resulting in intense irrigational activities along the bank of river Ngadda.

Pollution from the various activities which takes place along the river bank such as irrigation farming, urban development and land pollution (indiscriminate solid waste disposal) may result in water quality deterioration, changing the physico chemical parameters of aquatic ecosystem. This dynamism may disrupt the aquatic ecosystem, leading to migration, reduction or increase in productivity, booming in some species and resulting to death in others (Syed, 2011; Akan et al, 2013).

The study was aimed at assessing the impact of irrigational activities on fish biodiversity in river Ngadda, Maiduguri, Borno State, Nigeria.

\section{Materials and Methods Study Area}

Maiduguri is the capital and the largest city in Borno State, Nigeria. It is located on latitude $11^{\circ}$ $51^{\prime} 42^{\prime} ' \mathrm{~N}$ and longitude $013^{\circ} 09^{\prime}$ ' $35 \mathrm{E}$ and lies within the northern Sudan Savannah with distinct dry and wet (rainy) seasons. The town has an annual mean temperature of $37^{\circ} \mathrm{C}$. The town has two (2) main river systems (Nggadabul and Nggada Rivers) which met and continue to flow as River Nggada; both rivers are freshwater bodies which are remarkable for their circular shape (Bukar et al, 2016; Bwala, 2019).

Water from the river is used for irrigation, human consumption, domestic purposes and various industrial activities and the river receives runoff from the irrigated sites and effluent from Maiduguri Water Treatment plant, abattoir and dyeing industries located beside the river bank. This calls for systematic environmental monitoring to ensure the safety and health of the aquatic environment, (Adeniyi and Yusuf, 2007; Haruna and Anthony, 2011; Syed, 2011).

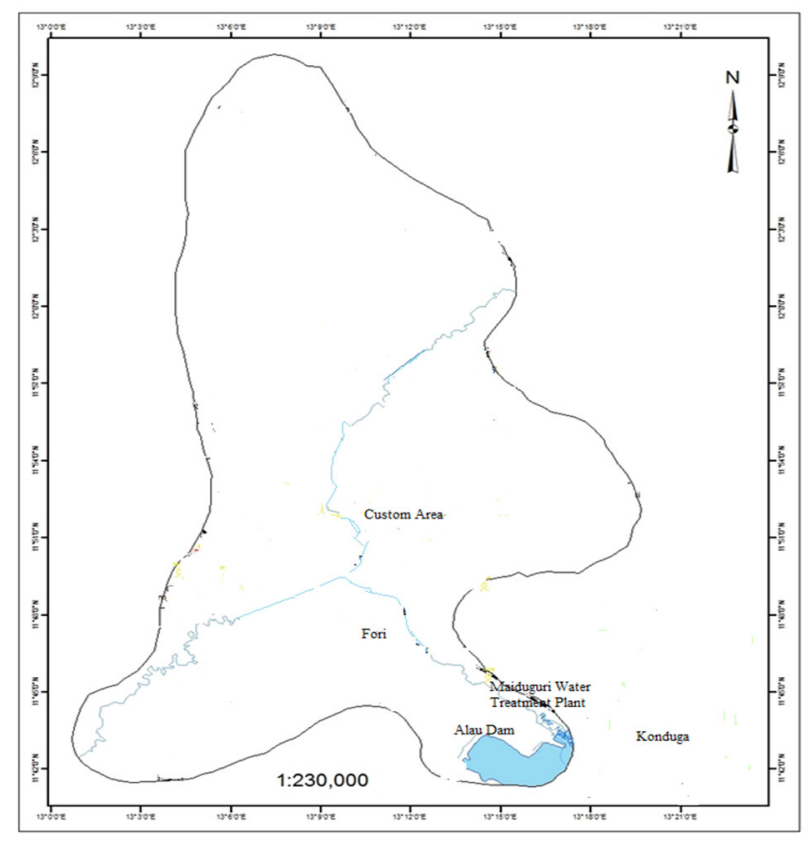

Fig 1: Map of Maiduguri Metropolis showing the sampling Stations. (Sharah, 2020)

\section{Sampling}

The river was divided into 4 different stations based on the irrigational activities along the bank of the river. A handheld Global Positioning System (GPS) device (GPSMAP 76CX) was used to obtain coordinates on all the sampling stations. 
Table 1: Sampling Stations

\begin{tabular}{|c|c|c|c|c|}
\hline $\begin{array}{l}\mathbf{S} / \\
\mathbf{N}\end{array}$ & STATION & LOCATION & $\begin{array}{l}\text { GPS } \\
\text { COORDINATE }\end{array}$ & $\begin{array}{l}\text { ACTIVITIES } \\
\text { / REMARK }\end{array}$ \\
\hline 1 & $\mathbf{A}$ & $\begin{array}{l}\text { Up Stream } \\
\text { Close to Alau } \\
\text { Dam }\end{array}$ & $\begin{array}{l}\mathrm{N} 11^{\circ} 44^{\prime} 11.8^{\prime \prime} \\
\text { E013 }\end{array}$ & $\begin{array}{l}\text { Non- } \\
\text { Irrigated } \\
\text { Site. }\end{array}$ \\
\hline 2 & B & $\begin{array}{l}\text { Beside Water } \\
\text { Treatment } \\
\text { Plant }\end{array}$ & $\begin{array}{l}\mathrm{N} 11^{\circ} 47^{\prime} 28.1^{\prime}, \\
\mathrm{E} 013^{\circ} 11^{\prime} 33.8^{\prime \prime}\end{array}$ & $\begin{array}{ll}\checkmark & \text { Irrigation } \\
& \text { sites } \\
\checkmark & \text { Topogra } \\
& \text { phy: } \\
& \text { Sloppy }\end{array}$ \\
\hline 3 & C & Fori ward & $\begin{array}{l}\mathrm{N} 11^{\circ} 48^{\prime} 10.2^{\prime \prime} \\
\mathrm{E}^{\prime} 3^{\circ} 10^{\prime} 18.9^{\prime}\end{array}$ & $\begin{array}{ll}\checkmark & \text { Domestic } \\
& \text { uses } \\
\checkmark & \text { Irrigation } \\
& \text { sites } \\
\checkmark & \text { Topogra } \\
& \text { phy: } \\
& \text { Sloppy }\end{array}$ \\
\hline 4 & D & Custom Area & $\begin{array}{l}\mathrm{N} 11^{\circ} 51^{\prime} 29.8^{\prime \prime} \\
\mathrm{E} 013^{\circ} 11^{\prime} 01.0^{\prime \prime}\end{array}$ & $\begin{array}{ll}\checkmark & \text { Irrigation } \\
& \text { sites } \\
\checkmark & \text { Topogra } \\
& \text { phy: flat } \\
\checkmark & \text { Wastewa } \\
& \text { ter from } \\
& \text { abattoir }\end{array}$ \\
\hline
\end{tabular}

\section{Drainage Flow Monitoring}

During irrigation events, pumping machine was used to irrigate the farmlands and some return to the river again as surface irrigation runoff with observable minor rill erosion. At Sampling Stations B - D a monitoring station was established at the edge of the rill erosion at the entering point to the river.

\section{Determination of Physico - chemical parameters}

Samples for determination of physico - chemical parameters were taken at the sampling stations from the point where the pumping machine was used to drain water and a representative sample from the monitoring station. Water surface temperature was determined using mercury thermometer at the sampling stations. Water samples were collected for analysis of total nitrogen (TN), ammonium $\left(\mathrm{NH}^{+}\right)$, total phosphorus (TP), total organic carbon (TOC), total dissolved solids (TDS), turbidity (Tur) and total suspended solids (TSS). A composite auto - sampler was installed at each sampling station to collect samples at intervals (biweekly) during irrigation seasons (November, 2018 - April, 2019). Samples collected were transported in ice to the laboratory for further water quality analysis by standard methods (APHA 2005); (Usman et al, 2016; Gwana et al, 2017) with slight modification.

Table 2: NESREA permissible limits of some physico - chemical parameters for fisheries and recreation quality criteria standards

\begin{tabular}{lll}
\hline S/N & $\begin{array}{l}\text { Physico }- \text { chemical Fisheries and } \\
\text { parameter }\end{array}$ & $\begin{array}{l}\text { recreation quality } \\
\text { criteria standards }\end{array}$ \\
\hline 1 & $\mathrm{NH}^{+}$ & $0.05(\mathrm{mg} / \mathrm{L})$ \\
2 & TSS & $0.25(\mathrm{mg} / \mathrm{L})$ \\
3 & TDS & $18(\mathrm{NTU})$ \\
4 & Turbidity & $15(\mathrm{mg} / \mathrm{L})$ \\
5 & Temperature & $\leq 40\left({ }^{\circ} \mathrm{C}\right)$ \\
\hline & Source: NESREA, 2011
\end{tabular}

Determination of Fish Relative Abundance

Capture and recapture method was employed to determine the relative abundance of fish. A representative sample was preserved with $40 \%$ alcohol and transported to the laboratory for species identification (Portt et al., 2016). The Lincoln Index was used to estimate the fish population size.

Population $=$

Total number of fish in 1 st Sample X Total mumber of fish in 2nd sample Number of marked fish in 2nd sample

(FSC, 2016)

\section{Results and Discussion}

The results of the study were presented in tables below and shows that most of the parameters measured were above the national permissible limits as set by the National Environmental Standards and Regulations Enforcement Agency (NESREA).

Table 3 presents the mean physico - chemical parameters of river Ngadda. The results indicates that Total Nitrogen (TN) ranges from $5.02 \mathrm{mg} / \mathrm{L}-$ $8.31 \mathrm{mg} / \mathrm{L}$, ammonium $\left(\mathrm{NH}^{+}\right)$ranges from 
$0.93 \mathrm{mg} / \mathrm{L}-2.01$, Total phosphorous (TP) ranges from $0.07 \mathrm{mg} / \mathrm{L}-1.81 \mathrm{mg} / \mathrm{L}$. Total Organic Carbon (TOC) ranges $5.87 \mathrm{mg} / \mathrm{L}-7.45 \mathrm{mg} / \mathrm{L}$, Turbidity (Tur) ranges from $27 \mathrm{mg} / \mathrm{L}$ - 31mg/L, Total Dissolved Solids (TDS) ranges 198NTU Page | 3984 298NTU, Total Suspended Solids ranges from $34 \mathrm{mg} / \mathrm{L}-47 \mathrm{mg} / \mathrm{L}$ and Temperature ranges from $26^{\circ} \mathrm{C}-28^{\circ} \mathrm{C}$.

It can be seen from Table 3 that Sampling Station A been an unirrigated zone has the lowest $\mathrm{NH}_{4}^{+}$ $(0.93 \mathrm{mg} / \mathrm{L})$, TP $(0.07 \mathrm{mg} / \mathrm{L})$ and TSS $(34 \mathrm{mg} / \mathrm{L})$. Station B is a sloppy irrigated zone with observable rill erosion as a result of surface runoff and has the highest TN $(8.31 \mathrm{mg} / \mathrm{L}), \mathrm{NH}^{+}(2.01 \mathrm{mg} / \mathrm{L}), \mathrm{TP}$ $(1.81 \mathrm{mg} / \mathrm{L})$, TOC $(7.45 \mathrm{mg} / \mathrm{L})$, TSS $(47 \mathrm{mg} / \mathrm{L})$ and Temperature $\left(28^{\circ} \mathrm{C}\right)$, it is worthy of note that this station also received a point source pollutant from Maiduguri Water Treatment Plant (sludge discharge) coupled with nonpoint source pollutant from the densely irrigated sites along the river bank affects the water chemistry, this agrees with (Akan et al, 2013; Gwana et al, 2017; Bwala, 2019).

Sampling Station C, has the highest mean turbidity $(31 \mathrm{mg} / \mathrm{L})$ with a relatively high $\mathrm{TN}(5.87 \mathrm{mg} / \mathrm{L})$, TOC $(6.69 \mathrm{mg} / \mathrm{L})$ was sloppy irrigated zone similarly, Sampling Station D was a flat irrigated zone which recorded the highest TDS 298NTU and receive wastewater from Maiduguri abattoir. The values of $\mathrm{NH}^{+}$, TDS and TSS are all above NESREA limit in all sampling stations (NESREA, 2011).

Table 4 presents the relative abundance of fish biodiversity in river Nggada. The results revealed a total of four (4) different families and ten (10) distinct species of fishes were identified in the sampling stations.

From Table 4, it can be seen that Station A has the highest relative abundance of fish (115.3), with the highest relative abundance of class Cichlidae (38.7), Characidae mochokidae (28.4) and surprisingly zero (0) presence of class Cyprinidae osteoglossidae. It was an unirrigated zone, with less anthropogenic activities and interference having the less mean TSS $(34 \mathrm{mg} / \mathrm{L}), \mathrm{TP}(0.07 \mathrm{mg} / \mathrm{L})$ and $\mathrm{NH}^{+}$ $(0.93 \mathrm{mg} / \mathrm{L})$ which may have favoured the growth and development of the fish species in the sampling (Portt et al, 2006; Harris, 2012). Tillipia zillli (73.7), Alestes nurse (81.2) and Clarias gariepinus (20.2) are the most abundant species, this agrees with Akan et al, (2013); Mshelia et al, (2015); Gwana et al, (2017).

Similarly, Table 4 revealed that Sampling Station D has the lowest relative abundance of fish species (34) using the Lincoln index, with relatively high abundance of class Cyprinidae osteoglossidae (4). The sampling station apart from being a flat irrigated land also receives point source pollutants (effluent) from the Maiduguri abattoir and has the highest TDS 298NTU and relatively high TSS $(41 \mathrm{mg} / \mathrm{L})$, Tur $(39 \mathrm{mg} / \mathrm{L})$, TP $(1.01 \mathrm{mg} / \mathrm{L})$ and surface water Temp. $\left(27^{\circ} \mathrm{C}\right)$ which may have adversely affected the abundance and distribution of fish species in the sampling station.

It can also be noted from the Tables 3 and 4 accordingly, that Sampling Station B, has a total relative abundance of fish species (86.9) using the Lincoln index, with zero (0) presence of Heterotis niloticus species in the class Cyprinidae osteoglossidae. The station has the highest TN $(8.31 \mathrm{mg} / \mathrm{L}), \mathrm{NH}^{+}(2.01 \mathrm{mg} / \mathrm{L}), \mathrm{TP}(1.81 \mathrm{mg} / \mathrm{L})$, TOC $(7.45 \mathrm{mg} / \mathrm{L})$, TSS $(47 \mathrm{mg} / \mathrm{L})$ and Temperature $\left(28^{\circ} \mathrm{C}\right)$, and receives a point source pollutant from Maiduguri Water Treatment Plant (sludge discharge) and also its bank is densely irrigated which may have charge the station with nonpoint source pollutant, this agrees with (Akan et al, 2013; Gwana et al, 2017; Bwala, 2019). This suggests that the class Cichlidae (28.1) and Characidae mochokidae (27.4) are tolerant species, while the class Claridae (4.2) and Cyprinidae osteoglossidae (2) as indicator species.

It can be seen from the results that Sampling Station D, has the highest TDS (298 NTU) and relatively high TSS (41 mg/L) and Tur (29 mg/L), and the lowest relative abundance of fish species (34) using 
the Lincoln index. This suggest that the physico chemical parameters may have effect on the fish abundance and distribution. There might have been some dissolve metals that might have inhibited the growth and survival of the fish species, impacting Page | 3985 adversely on their abundance and distribution in the sampling station. The abundance and distribution of fish species is impacted by the dynamism of the physico - chemical characteristic of the river, as the data is slightly lower than the findings of Mshelia et al., 2015 and Gwamna et al., 2017.

Table 3: Mean Physico - chemical parameters of the Sampling Stations

\begin{tabular}{ccccccccc}
\hline Stations & $\begin{array}{c}\text { TN } \\
(\mathbf{m g} / \mathbf{L})\end{array}$ & $\begin{array}{c}\mathbf{N H 4}^{+} \\
(\mathbf{m g} / \mathbf{L})\end{array}$ & $\begin{array}{c}\text { TP } \\
(\mathbf{m g} / \mathbf{L})\end{array}$ & $\begin{array}{c}\text { TOC } \\
(\mathbf{m g} / \mathbf{L})\end{array}$ & $\begin{array}{c}\text { Tur } \\
(\mathbf{m g} / \mathbf{L})\end{array}$ & $\begin{array}{c}\text { TDS } \\
(\mathbf{N T U})\end{array}$ & $\begin{array}{c}\text { TSS } \\
(\mathbf{m g} / \mathbf{L})\end{array}$ & $\begin{array}{c}\text { Temperature }^{\circ} \\
\left.\mathbf{(}^{\circ} \mathbf{C}\right)\end{array}$ \\
\hline $\mathbf{A}$ & 5.12 & 0.93 & 0.07 & 5.87 & 29 & 203 & 34 & 27 \\
$\mathbf{B}$ & 8.31 & 2.01 & 1.81 & 7.45 & 27 & 238 & 47 & 28 \\
$\mathbf{C}$ & 5.87 & 1.09 & 0.92 & 6.69 & 31 & 198 & 35 & 26 \\
$\mathbf{D}$ & 5.02 & 1.72 & 1.01 & 5.98 & 29 & 298 & 41 & 27 \\
NESREA & - & 0.05 & - & - & 15 & 18 & 0.25 & $\leq 40$ \\
Standards & & & & & & & & \\
\hline
\end{tabular}

Table 4: Relative Abundance of Fish (Lincoln Index)

\begin{tabular}{ccccccc}
\hline S/N & FAMILY & A & B & C & D & TOTAL \\
\hline $\mathbf{A}$ & CICHLIDAE & & & & & \\
$\mathbf{1}$ & Tillipia zillii & 34.6 & 25.1 & 12 & 2 & 73.7 \\
$\mathbf{2}$ & Oreochromis niloticus & 2.1 & 2 & 0 & 0 & 4.1 \\
$\mathbf{3}$ & Himechromis bimaculatus & 2 & 1 & 1 & 0 & 4 \\
Total & CLARIDAE & 38.7 & 28.1 & 13 & 2 & \\
$\mathbf{B}$ & Clarias gariepinus & 12 & 2 & 5.2 & 1 & 20.2 \\
$\mathbf{4}$ & Clarias ngularis & 4.2 & 3.2 & 18.6 & 4 & 30 \\
$\mathbf{5}$ & CYPRINIDAE OSTEOGLOSSIDAE & 14.2 & 4.2 & 23.8 & 5 & \\
Total & Labeo sengalensis & 0 & 2 & 2.1 & 2 & 6.1 \\
$\mathbf{C}$ & Heterotis niloticus & 0 & 0 & 3 & 2 & 5 \\
$\mathbf{6}$ & & 0 & 2 & 5.1 & 4 & \\
$\mathbf{7}$ & CHARACIDAE MOCHOKIDAE & & & & & \\
Total & Synodontis nigrita & 1.2 & 2 & 3.1 & 0 & 6.3 \\
$\mathbf{D}$ & Synodontis eupterus & 2 & 2.4 & 4.1 & 1 & 9.5 \\
$\mathbf{8}$ & Alestes nurse & 25.2 & 23 & 21 & 12 & 81.2 \\
$\mathbf{9}$ & & 28.4 & 27.4 & 28.2 & 13 & \\
$\mathbf{1 0}$ & OTHER FAMILY & & & & & \\
Total & Other Species & 32 & 24.2 & 23 & 10 & 89.2 \\
$\mathbf{E}$ & & 115.3 & 86.9 & 93.1 & 34 & 329.3 \\
$\mathbf{1 1}$ & & & & & \\
\hline GRAND & & & & & \\
TOTAL & & & & & \\
\hline
\end{tabular}




\section{Conclusions}

The irrigational runoffs into river Ngadda is an emerging ecological concern with the sky rocking irrigational activities along the river bank. The Page | 3986 Physico - chemical parameters of the river are slightly above NESREA permissible limited, which calls the need for systematic monitoring of this aquatic ecosystem.

The findings indicate that the classes Cichlidae and Characidae Mochokidae are less disturbed and more tolerant to the changing physico chemical parameters and has such can be consider as "tolerant species" in river Ngadda as against claridae) and Cyprinidae osteoglossidae which are more affected by the aquatic environmental dynamism and can be said to be the "Indicators species" of river Ngadda.

\section{Acknowledgement}

I will like to appreciate the staff and management of NESREA Borno for granting me the permission to use some of its facilities and acknowledge Mr. Charles Joshua Sharah (NESREA, Borno State Coordinator) for ensuring the quality of this study. I wish to also acknowledge NAFDAC, Maiduguri for subsiding the cost of analysis and other logistics.

\section{Competing interests}

Authors have declared that no competing interests exist.

\section{References}

Adeniyi, A. A. and Yusuf, K. A. (2007). Determination of heavy metals in fish tissues, water and bottom sediments from Epe and Badagry Lagoons, Lagos, Nigeria Environmental Monitoring Assessment 37, 451-458.

Akan, J. C., Mohammed, Z., Jafiya, L. and. Ogugbuaja, V. O. (2013). Organochlorine Pesticide Residues in Fish Samples from
Alau Dam, Borno State, North Eastern Nigeria. Journal of Environmental \& Analytical Toxicology, 3(3): 1-7.

APHA, (2005). Standard methods for the examination of water and wastewater, $21 \mathrm{st}$ edition. American Public Health Association.

Bukar, P. H., Zakari, I. Y., Oladipo, M. O. A., and Ibeanu, I. G. E. (2016). Assessment and Distribution of Metal Pollutants in the Sediments of River Ngadda and Alau Dam in Maiduguri, Borno State, Nigeria. American Journal of Research Communication, 4(4).

Bwala, M.N. (2016). The Effect of Physicochemical Parameters on Phytoplankton and Ostracods of Some Selected Waterbodies in Maiduguri Metropolis, Borno State. Undergraduate Student's Project submitted to Biological Science Department, University of Maiduguri

Bwala, M. N. (2019). The Abundance of Phytoplankton in River Nggada and River Ngadda-Bul, Maiduguri Metropolis, Borno State, Nigeria. Global Educational Research Journal, 7(7) 820-829

Causapé, J., Quílez, D., and Aragüés, R. (2004). Assessment of irrigation and environmental quality at the hydrological basin level II. Salt and nitrate loads in irrigation return flows. Agricultural Water Management, 70, $211-228$.

Field studies Council (FSC) (2016). Field Studies Council, a Limited Company, reg. England and Wales No.412621,

George, E. E., Samuel, I. U. and Andem, A. B. (2012). Composition and abundance of Phytoplankton of Adiabo River in Calaber River System, Southeast Nigeria. European 
Journal of Zoological Research, 1 (4) 93 98.

Govind, P. (2012). Handbook of Conservation Biology. Discovery Publishing House PVT Page | 3987 Ltd, New Delhi - 110 002. ISBN 978-935056-003-7

Gwana, A.M., Umaru, B.W., Halima, M.B. and Wanas, L. N. (2017). Physico - Chemical Water Quality Analyses of Lake Alau, North - Eastern Nigeria, Journal of Water Resources and Ocean Science, 6(1) 14-22.

Harris, F. (2012). Global Environmental Issues. Wiley-Blackwell, A John Wiley \& Sons Ltd Publications. ISBN 978-0-470-68470-2 (cloth) - ISBN 978-0-470-68469-6 (pbk)

Haruna, K. A. and Anthony, D. (2011). Environmental Sciences: An Introductory Text. Apani Publications. ISBN 978-978088-927-2

https://www.unicef.org/nigeria/pressreleases/19-million-children-internallydisplaced-conflict-and-violence-2019highest-number (retrieved on the 11/12/ 2020)

Ingjerd, H., Dennis, P. and Lettenmaier, T. S. (2006). Effects of irrigation on the water and energy balances of the Colorado and Mekong river basins. Journal of Hydrology 324(15) 210-22

Lilly-Rose, L., Pierre, P., Isabelle, B., Blandine, C., Loïc, M., Judicaël, D., Emmanuel, H. and Pascal, B. (2016). Description and evaluation of a surface runoff susceptibility mapping method. Journal of Hydrology 541: $495-50$

Luke M. Mosley and Nigel Fleming (2010). Pollutant Loads Returned to the Lower Murray River from Flood-Irrigated Agriculture. Water Air Soil Pollution, 211:475-487
Mshelia, M. B., Manneer, M. B., Garba, U. and Hassan, M. (2015). A frame and catch assessment of fishes of lake Alau, Borno State, Nigeria. International Journal of Fisheries and Aquatic Studies, 2(45): 35-40

NESREA, (2011). National Environmental (Surface and Groundwater Quality Control) Regulation.

Portt, C.B., Coker, G.A., Ming, D.L. and Randal, R.G. (2006). A review of fish sampling methods commonly used in Canadian freshwater habitats. Canadian Technical Report of Fisheries and Aquatic Sciences, 2604

Ron, G. (2012). The Problem of Runoff. Pesticide Environmental Stewardship.

Sharah, J. C. (2020). Assessment of Base Transceiver Stations Compliance to Environmental Standards in Maiduguri Metropolis, Borno State Nigeria. Unpublished MSc Thesis submitted to the Department of Geography, University of Maiduguri, Borno State - Nigeria.

Shunsuke, C., Shigeya, M., Thbshihiko, K., Koichi, U. and Junichiro, T. (2009). Dynamics of Nonpoint Source Pollutant Loadings from Agricultural Watershed. Journal of Rainwater Catchment Systems. 14(2): $21-28$

Syed, A. I. (2011). Pollution: The Ugly Face of Environment. Discovery Publishing House PVT Ltd, New Delhi - 110 002. ISBN 97881-8356-810-4

Usman, Y. M., Mohammed, A., Ibrahim, B. and Saleh, B. A. (2016). Assessment of Groundwater Quality Status along River Nggada in Maiduguri, Nigeria. International Journal of Engineering and Sciences (IJES), 5(1) $08-14$. 
Verma, P. S. and Agarwal, V. K. (2008). Environmental Biology (Principles of Ecology). S. Chand \& Company Limited Publishers. ISBN: 81-219-0859-0

Page | 3988 